\title{
Penggunaan Media E-mail sebagai Sarana Beracara Contante Justitie pada Pengadilan di Indonesia
}

\author{
The Uses of E-mail as a Medium on the Contante Justitie Proceedings \\ on the Courts in Indonesia
}

\author{
Yasser S. Wahab ${ }^{1}$, Julianto J.J. Kalalo² ${ }^{\text {, Lisa Mery }}{ }^{3}$ \\ ${ }^{1}$ Kantor Advokat Yasmin Faizah Yuristiana \\ Jln. Topas Raya No. 5, Panakkukang, Makassar, Sulawesi Selatan, 90231, Indonesia. \\ Tel./Fax:+62-411454158E-mail: obebuyung@yahoo.com \\ ${ }^{2}$ Fakultas Hukum Universitas Musamus Merauke \\ Jln. Kamizaun Mopah Lama, Merauke, Papua, 99600, Indonesia \\ Tel./Fax: +62-971325976 E-mail: jover_kalalo@yahoo.com \\ ${ }^{3}$ Fakultas Hukum Universitas Indonesia Timur \\ Jln. Rappocini Raya, Kota Makassar, Sulawesi Selatan, 90222 Indonesia \\ Tel./Fax:+62-411421974E-mail: lis1879@yahoo.com \\ Submitted: Jun 17, 2014; Reviewed: Jul 9, 2015; Accepted: Aug 3, 2015
}

\begin{abstract}
This research aims to know how the contante justitie principle may be applied into the enforced legislations in Indonesia, and to investigate the synergy of proceedings by means of e-mail in realizing contante justitie. The research employed in this paper is normative research, using both primary and secondary legal sources. Primary sources obtained from compiling relevant rules on the research concerned, in addition to secondary sources taken from books, court decisions, newspapers, internet materials and others relevant with the issue; that is to oversee the contradictions of humanist and mechanical processes when utilizing the internet e-mail for the court proceedings. The use of internet media e-mail in the correspondence process is expected to cut down the time, cost and potential instability. Thus strongly supports the realization of the principle of contante justitie in court proceedings more effectively and efficiently.
\end{abstract}

Keywords: Contante Justitie; E-mail; Judicial Power; Law Reform

\begin{abstract}
Abstrak: Penelitian ini untuk mengetahui bagaimana penerapan asas constante justitie pada peraturan perundang-undangan yang berlaku di Indonesia, serta untuk mengetahui sinergitas proses beracara jika menggunakan sarana media internet e-mail dalam mewujudkan contante justitie. Penelitian ini merupakan penelitian normatif. Penelitian dilakukan secara kualitatif dengan bertumpu pada studi kepustakaan (library research) dengan pendekatan bahan hukum primer dan bahan hukum sekunder. Hasil penelitian mengindikasikan bahwa meski prinsip contante justitie telah diatur dalam ketentuan peraturan perundang-undangan di Indonesia, yaitu pada Pasal 2 ayat (4) Undang-Undang Nomor 48 tahun 2009 tentang Kekuasaan Kehakiman, namun pada praktiknya masih ketinggalan zaman, khususnya pada proses beracara jawabmenjawab, karena dilaksanakan secara "tradisional" dengan mewajibkan para pihak untuk menghadiri dan mengajukan surat (secara fisik) di depan persidangan.
\end{abstract}

Kata Kunci: Contante Justitie; E-mail; Kekuasaan Kehakiman; Pembaharuan Hukum 


\section{PENDAHULUAN}

Pasal 2 ayat (4) Undang-Undang Nomor 48 Tahun 2009 tentang Kekuasaan Kehakiman, menentukan bahwa peradilan dilakukan dengan sederhana, cepat, dan biaya ringan. Asas sederhana, cepat dan biaya ringan (contante justitie) adalah asas peradilan yang paling mendasar dari pelaksanaan dan pelayanan administrasi peradilan yang mengarah pada prinsip dan asas efektif dan efisien. ${ }^{1}$

Tahapan-tahapan proses beracara saat ini masih banyak memakan waktu dan biaya ketimbang manfaat dan tujuan acara itu sendiri, termasuk proses jawab menjawab (pengajuan jawaban, pengajuan replik dan pengajuan duplik dan pengajuan kesimpulan). Sedangkan esensi dari proses jawabmenjawab belum saatnya untuk didebat, diinterupsi ataupun belum saatnya dilakukan cross examination oleh pihak lain. Sehingga proses yang memakan waktu bermingguminggu ini, sebenarnya hanyalah proses mengantarkan, membagikan dan menerima surat, yang seyogyanya hanya memakan waktu tidak lebih dari 10 menit.

Namun karena harus dilakukan di depan persidangan, maka proses 10 menit tersebut menjadi membengkak bisa menjadi sehari penuh akibat antrian jadwal persidangan pada hari yang sama, yang berulang lagi selama beberapa minggu. Proses jawabmenjawab ini tidak hanya banyak membuang waktu seluruh pihak, bahkan juga memakan biaya yang tidak sedikit yang dikeluarkan oleh para pihak setiap kali menghadiri persidangan "serah terima surat" tersebut.

Sunaryo, T.M., Tjoek, W dan Aris, H., (2004). Pengelolaan Sumber Daya Air. Denpasar: Universitas Udayana., hlm. 46
Seiring dengan perkembangan zaman, maka saat ini sudah dikenal adanya media internet. Di mana perkembangan media internet ini termasuk pula suatu sistem yang disebut sebagai e-mail (electronic mailing). Sistem E-mail ini ternyata efektif dan efisien dalam mempercepat proses surat-menyurat dari satu pihak ke pihak lainnya. Pada sistem surat menyurat yang tradisional, memerlukan waktu paling cepat 1 (satu) hari untuk mengirim/mengantar hingga surat tersebut sampai kepada pihak yang ditujukan. Sedangkan jika menggunakan e-mail, maka waktu bisa dipersingkat menjadi hitungan detik, serta biaya yang dibutuhkan juga relatif sangat kecil dibandingkan jika surat harus dikirim/diantar secara tradisional.

Berdasarkan uraian permasalahan tersebut, maka tulisan ini bertujuan untuk menganalisis penerapan asas contante justitie pada praktiknya dalam sistem peradilan di Indonesia, serta kaitannya dengan sinergitas proses beracara jika menggunakan sarana media internet e-mail untuk mewujudkan asas contante justitie.

\section{METODE}

Penelitian ini merupakan penelitian normatif (doktrinal research $)^{2}$ dengan mengkaji kontradiksi proses humanis dan proses mekanis jika menggunakan media internet e-mail dalam proses beracara di pengadilan. Tulisan ini menggunakan bahan hukum primer dan sekunder. Bahan hukum primer diperoleh dari peraturan perundang-undangan yang relevan dengan isu penelitian, ditambah dengan bahan hukum sekunder yang diperoleh

2 Zainuddin Ali. (2011). Metode Penelitian Hukum. Ed. 1 Cet. 3. Jakarta: Sinar Grafika, hlm. 24-25. 
dari sejumlah buku-buku, putusan pengadilan, surat kabar, sumber internet dan sumber lain yang relevan dengan isu penelitian. Metode kuantitatif digunakan untuk mengukur seberapa besar deviasi cepat, sederhana dan besarnya biaya yang diperlukan antara proses beracara yang sekarang berlaku dengan proses jika menggunakan media internet e-mail.

\section{ANALISIS DAN PEMBAHASAN}

Penerapan Asas Contante Justitie Menurut Peraturan Perundang-undangan yang

\section{Berlaku di Indonesia}

Asas-asas hukum (rechtsbeginselen; legal principles; principles of law) bukanlah peraturan hukum konkrit, melainkan pikiran dasar yang umum sifatnya atau merupakan latar belakang dari "hukum positif" yang terdapat dalam dan di belakang setiap sistem hukum yang terjelma dalamperaturan perundang-undangan ${ }^{3}$. Asas hukum yang dimaksud adalah yang kita kenal dengan istilah Rechtsbeginselen dalam bahasa Belanda, yang berarti asas umum hukum yang diakui oleh bangsa beradab dan dilakukan oleh badan pengadilan internasional sebagai kaidah hukum ${ }^{4}$.

Asas hukum (rechts beginsellen) merupakan salah satu bagian dari kaidah hukum. Asas hukum bersifat umum dan abstrak, sehingga ia menjadi ruh dan spirit dari suatu perundang-undangan. Pada umumnya asas hukum itu berubah mengikuti kaidah hukumnya, sedangkan kaidah hukum akan

Paul Scholten. (1988). Verzamelde Geschriffen, definitif Sudikno Mertokusumo, Mengenal Hukum. Yogyakarta: Liberty, hlm.33.

4 Algera, et. al., (1983). Kamus Istilah Hukum Indonesia Belanda, Jakarta. Hlm. 24 berubah mengikuti perkembangan masyarakat, jadi terpengaruh waktu dan tempat. ${ }^{5}$

Pengertian dari asas hukum yang dikemukakan para ahli, diantaranya:

1) Bellefroid menyatakan bahwa asas hukum umum adalah norma dasar yang dijabarkan dari hukum positif dan yang oleh ilmu hukum tidak dianggap berasal dari aturan-aturan yang lebih umum. Asas hukum umum itu merupakan pengendapan hukum positif dalam suatu masyarakat. ${ }^{6}$

2) Van Eikema Hommes menyatakan asas hukum adalah dasar-dasar atau petunjuk arah dalam pembentukan hukum positif. Asas hukum tidak boleh dianggap sebagai norma-norma hukum yang konkrit, tetapi dipandang sebagai dasar-dasar umum atau petunjuk-petunjuk bagi hukum yang berlaku. Pembentukan hukum praktis perlu berorientasi pada asas-asas hokum tersebut. ${ }^{7}$.

3) Paul Scholten berpendapat bahwa asas hukum adalah kecenderungan-kecenderungan yang disyaratkan oleh pandangan kesusilaan kita pada hukum, merupakan sifat-sifat umum dengan segala keterbatasannya sebagai pembawaan yang umum itu, tetapi yang tidak boleh tidak harus ada. ${ }^{8}$

4) Satjipto Rahardjo, berpendapat bahwa asas hukum adalah jantungnya peraturan hukum, karena asas hukum merupakan landasan yang paling luas bagi lahirnya suatu peraturan hukum, bahwa peraturan-peraturan hukum itu pada akhirnya dapat dikembalikan kepada asas-asas tersebut. Di samping itu, asas hukum layak disebut sebagai

Bambang Sutiyoso. (2007). Metode Penemuan Hukum, Cet. 2. Yogyakarta: UII Press, 2007, hlm. 52.

6 Notohamidjojo. (1957). Soal-Soal Pokok Filsafat Hukum. Jakarta: BPK Gunung Mulia, hlm. 49. Ibid

Sudikno. (2006). Hukum Acara Perdata, Edisi VII, Cet. 1. Yogyakarta: Liberty, hlm. 43 
alasan lahirnya peraturan hukum, atau merupakan ratio legis dari peraturan hukum. Dengan adanya asas hukum, maka hukum bukanlah sekedar kumpulan peraturan-peraturan, karena itu mengandung nilai-nilai dan tuntutantuntutan etis. ${ }^{9}$

5) Sri Soemantri Martosuwignjo, mengemukakan bahwa asas mempunyai padanan dengan 'beginsel' atau 'principle' sebagai suatu kebenaran yang menjadi pokok dasar atau tumpuan berpikir. Asas hukum adalah dasar normatif untuk membedakan antara daya ikat normatif dan keniscayaan yang memaksa. ${ }^{10}$

6) Huijbers berpendapat bahwa asas hukum adalah prinsip-prinsip yang dianggap dasar atau fundamen hukum atau pengertian dan nilai-nilai yang menjadi titik tolak berpikir tentang hukum atau titik tolak bagi pembentukan undangundang dan interpretasi undang-undang atau prinsip-prinsip yang kedudukannya lebih tinggi daripada hukum yang ditentukan manusia. ${ }^{11}$

Berarti asas-asas hukum adalah dasardasar atau petunjuk arah (richtlijn) dalam pembentukan hukum positif, yang oleh D.H.M. Meuwissen diungkapkan: ${ }^{12}$

"Daaraan ontleent het positieve recht zijn 'rechtszin'. Daarin ligt ook het onterium waarmee dekwaliteit van heit recht kan worden beoordeeld ...

Satjipto Rahardjo. (1986). Ilmu Hukum. Bandung: Alumni, hlm. 89.

10 Khudzaifah Dimyati. (2004). Teorisasi Hukum, Cet. 2. Yogyakarta: Muhammadiyah University Press, hlm 194. Lihat juga T. Mohammad Radhie, Pembangunan Hukum Nasional dalam Perspektif Kebijakan, Makalah, FHUII, Yogyakarta.

11 Abdul Ghofur. (2006). Filsafat Hukum, Cet. 1. Yogyakarta: Gajah Mada University Press, hlm 107.

12 Bruggink. (1999). Refleksi tentang Ilmu Hukum, Alih Bahasa: Arief Sidharta. Bandung: Citra Aditya Bakti, hlm 132. het recht wordt begrepen tegen de achtergrondvan een begisel ... van een fundered principe."

(Dari asas itulah hukum positif memperoleh makna 'hukumnya'. Di dalamnya juga terdapat kriterium yang dengannya kualitas dari hukum itu dapat dinilai...hukum itu dapat dipahami dengan berlatar belakang suatu asas... suatu asas yang melandasi).

Secaraluas, asas (principle) adalah suatu dalil umum yang dinyatakan dalam istilah umum tanpa menyarankan cara-cara khusus mengenai pelaksanaannya yang ditetapkan pada serangkaian perbuatan untuk menjadi petunjuk yang tepat bagi perbuatan itu, atau: "Beginselen zijn fundamentele opvattingen en gedachten die aan maatschappelijke gedragingenten grondslag liggen (asas-asas adalah anggapan-anggapan dan pertimbangan-pertimbangan fundamental yang merupakan dasar diletakkannya tingkah laku kemasyarakatan). ${ }^{13}$

Asas hukum pada dasarnya dapat dibedakan menjadi asas hukum umum dan asas hukum khusus. Asas hukum umum adalah asas hukum yang berhubungan dengan seluruh bidang hukum,seperti asas restitution in integrum, lex posterior derogate legi priori, equality before the law, resjudicata proveritate habetur, dan sebagainya. Asas hukum khusus hanya berfungsi atau berlaku dalam bidang hukum yang lebih sempit, seperti bidang hukum perdata, HAN, pidana dan sebagainya yang sering merupakan penjabaran dari asas hukum yang umum. Misalnya asas pactasun servanda dan asas konsensualisme dalam hukum perdata, asas presumption of innocence dan asas non retroaktif dalam hukum acara pidana, asas-asas umum pemer-

13 Ibid. 
intahan yang baik (good governance) dalam HAN, asas contante justitie dalam Hukum Acara dan sebagainya. ${ }^{14}$

Sejalan dengan deskripsi pengertian asas-asas hukum terurai diatas, O. Notohamidjojo mengetengahkan empat macam fungsi asas-asas hukum: ${ }^{15}$

1) Peraturan perundang-undangan harus mempergunakan asas-asas hukum sebagai pedoman (richtlijnen) bagi pembentukan hukum (positiveringsarbied).

2) Hakim seharusnya dan sepatutnya bekerja dengan asas-asas hukum apabila ia harus melakukan interpretasi pada penafsiran artikel-artikel yang kurang jelas, dan dengan menggunakan asas hukum hakim dapat mengadakan penetapan (precisering) dari pada keputusan-keputusannya.

3) Hakim perlu mempergunakan rechtsbeginselen apabila ia perlu mengadakan analogi. Analogi dapat dipakai apabila kasus A mirip dengan kasus B. Hakim menjabarkan dari peraturan tentang kasus A, suatu peraturan yang umum, yang dikenakan pada kasus B.

4) Hakim dapat melakukan koreksi terhadap peraturan undang-undang, apabila peraturan undang-undang itu terancam kehilangan maknanya.

Keempat macam fungsi asas-asas hukum yang diungkapkan O. Notoharmidjojo tersebut, dengan sederhana (simpellijk) dapat disarikan sebagaimana ditegaskan oleh A. Soeteman bahwa: "rechtsbeginselen zien functi-oneren in wetgeving en

14 Bambang Sutiyoso. Op. Cit, hlm 23-24.

15 Suparto. (1975). Demi Keadilan dan Kemanusiaan, Beberapa Cabang Filsafat Hukum. Jakarta: BPK Gunung Mulia, hlm. 49-50. rechtspraak". ${ }^{16}$ Maka sebagai intisari, fungsi asas-asas hukum itu adalah: ${ }^{17}$ Pertama, bagi pembuat undang-undang (wetgever), asasasas hukum merupakan pedoman dalam pembuatan undang-undang (wetgeving)- peraturan perundang-undangan; Kedua, bagi hakim (rechter), asas-asas hukum menolong untuk mencermatkan interpretasi danmembantu dalam pengenaan analogi serta mengarahkan dalam memberikan koreksiterhadap peraturan perundang-undangan.

Paton menyebutkan sebagai suatu sarana membuat hukum itu hidup, tumbuh dan berkembang dan ia menunjukkan, bahwa hukum itu bukan sekedar kumpulan dari peraturan-peraturan belaka. Dengan kata lain, asas-asas hukum itu bukanlah peraturan hukum (een rechtsbeginselen is niet een rechtsregel), namun tidak ada hukum yang bisa dipahami tanpa mengetahui asas-asas hukum yang melandasinya (het recht is echter neit te begrijpen zonder die beginselen - vunderend principle).

Untuk memahami peraturan hukum (rechtsregel) dengan sebaik-baiknya tidak bisa hanya melihat pada "rechtsregel"-nya saja, melainkan harus menggali sampai pada "rechtsbeginselen"-nya. Dengan demikian, asas-asas hukum tampak sebagai pengarah umum bagi "positivering” hukum oleh pembuat undang-undang dan hakim dalam mewujudkan tendensi etis (ethische tendenzen,algemene richtlijnen voor positivering van het recht door wetgever en rechter). Asas-asas hukum adalah maksud untuk menganjurkan apa yang seharusnya menurut hukum (wet rechtens behoortte

16 Ibid.

17 Ibid. 
zjin"). ${ }^{18}$ Ini merupakan suatu pemaknaan umum dan masih sangat luas terhadap asasasas hukum yang kepadanya pengertian asas-asas hukum dapat dikembalikan dan disandarkan. ${ }^{19}$

Asas hukum berfungsi baik di dalam maupun di belakang sistem hukum positif. Asas hukum itu dapat berfungsi demikian karena berisi ukuran nilai. Sebagai kaidah penilaian asas hukum itu mewujudkan kaidah hukum tertinggi dari suatu sistem hukum positif. Itu sebabnya asas-asas hukum itu adalah fondasi dari sistem tersebut. Karena itu, asas hukum harus dikonkritisasikan. Pembentuk undang-undang membentuk aturan hukum, yang didalamnya ia merumuskan kaidah perilaku.

Selanjutnya, konkritisasi dalam kaidah perilaku ini terjadi melalui generalisasi putusan-putusan hakim. Jika pengkonkritisasian telah terjadi dan sudah ditetapkan (terbentuk) aturan-aturan hukum positif dan putusan-putusan, maka asas hukum tetap memiliki sifat sebagai kaidah penilaian. Dengan itu maka fungsi kedua asas hukum tampil kepermukaan. Ukuran nilai yang diberikan asas hukum itu sulit untuk diwujudkan secara sepenuhnya. Dengan itu, asas hukum dapat tetap berada berhadapan dengan sistem hukum positif dan berfungsi sebagai batu-uji kritis (kritischetoetssteen). ${ }^{20}$

Berbagai kemungkinan dapat terjadinya pertentangan dalam suatu sistem hukum, misalnya pertentangan diantara satu peraturan perundang-undangan dengan peraturan perundang-undanganyang lain, baik

18 Paul Scholten, Op.Cit. Lihat juga Sudikno, hlm. 33; Notodiharjo, hlm 49; Suparto, hlm. 47

19 Suparto, Op.Cit. hlm. 48

20 Bruggink, Op. Cit. hlm.132 pertentangan secara vertikal maupun pertentangan secara horizontal karena berlakunya prinsip lex superior derogate legi inferiori, prinsip lex posteriori derogate legipriori, dan prinsip lex specialis derogate legi generali. Masalah pokoknya ialah, bagaimana mengatasi terjadinya pertentangan-pertentangan, batasan-batasan perbedaan diantara ketentuan peraturan perundang-undangan sebagai sub-sistem atau sistem hukum dalam satu kesatuan sistem hukum nasional, sehingga tidak terhalang oleh perbedaanperbedaan dan tidakt erjadi duplikasi atau tumpang tindih.

Di antara peraturan perundang-undangan sebagai suatu sistem tersebut berkaitan dengan sistem hukum secara keseluruhan yaitu sistem hukum nasional. Keterkaitan yang harmonis, selaras, serasi, seimbang, konsisten dan taat asas, yang dijiwai Pancasila dan bersumber pada UUD 1945. Dengan demikian keharmonisan dapat dipertahankan atau diciptakan keharmonisan sistem hukum secara keseluruhan dalam kerangka sistem hukum nasional.

Menurut Bellefroid sebagaimana dikutip oleh Sudikno Mertokusumo, ${ }^{21}$ asas hukum umum adalah norma yang dijabarkan dari hukum positif dan oleh ilmu hukum tidak dianggap berasal dari aturan-aturan yang lebih umum yang merupakan pengendapan hukum positif dalam masyarakat. Pengertian asas hukum umum yang dirumuskan oleh Bellefroid, merupakan pengertian yang berbeda dengan rumusan asas dalam ilmu hukum. Sebaliknya, van Eikema Hommes sebagaimana dikutip oleh Sudikno Mer-

21 Kusnu Goesnadhie. (2006). Harmonisasi Hukum, Cetakan pertama. Surabaya: JP. Books, hlm. 71. 
tokusumo ${ }^{22}$, menyatakan asas hukum tidak boleh dianggap sebagai norma-norma hukum konkrit, tetapi harus dipandang sebagai dasar-dasar umum atau petunjuk bagi hukum yang berlaku. Pembentukan hukum harus berorientasi pada asas-asas hukum tersebut sehingga menjadi dasar atau petunjuk arah dalam pembentukan hukum positif.

Kedua rumusan tersebut di atas mempunyai perbedaan yang prinsip, sebab yang dimaksud oleh Bellefroid asas hukum umum adalah asas dalam hukum, sedangkan yang dimaksud oleh van Eikema Hommes asas hukum adalah asas dalam ilmu hukum. Dengan demikian asas hokum dapat merupakan norma hukum konkrit bersifat normatif, termasuk hukum positif yang mempunyai kekuatan mengikat yang dirumuskan oleh pembuat undang-undang ataupun hakim. Asas hukum demikian ini disebut asas dalam hukum. Selain itu, asas hukum dapat pula merupakan norma hukum abstrak yang merupakan dasar, landasan, prinsip, fundamen, nilai-nilai atau cita-cita yang ingin diwujudkan melalui peraturan hukum konkrit. Asas hukum seperti ini disebut asas dalam ilmu hukum. Karena itu fungsi dari asas hukum tersebut dapat pula dibedakan antara fungsinya dalam hukum dan fungsinya dalam ilmu hukum.

Asas hukum yang baik adalah asas hukum yang sudah ada dan diakui maupun yang sepatutnya diakui atau dikembangkan sebagai asas hukum nasional. Pengembangan asas-asas hukum nasional itu sendiri harus berorientasi masa depan (futurologistsistemati-holistik). Sumber asas hukum nasional bersumber pada pandangan hidup

22 Ibid. bangsa Indonesia yaitu Pancasila, nilai-nilai yang terkandung dalam UUD NRI 1945, yurisprudensi serta hukum kebiasaan. Contante Justitie adalah suatu asas dalam peradilan yaitu asas peradilan cepat, sederhana dan biaya ringan. Asas ini dituangkan dalam Pasal 2 ayat (4) UU No. 48 Tahun 2009 tentang Kekuasaan Kehakiman.

Dari asas tersebut, kata cepat harus dimaknai sebagai upaya strategis yang menjadikan sistem peradilan sebagai institusi yang dapat menjamin terwujudnya/tercapainya keadilan dalam penegakkan hukum secara tepat oleh pencari keadilan. ${ }^{23}$ Kata "cepat" juga menunjuk kepada jalannya peradilan. Terlalu banyak formalitas merupakan hambatan bagi jalannya peradilan. Makin cepatnya jalan peradilan akan meningkatkan kewibawaan pengadilan dan menambah kepercayaan masyarakat pencari keadilan kepada pengadilan.

Sederhana dimaksud sebagai pemeriksaan dan penyelesaian perkara yang harus dilakukan dengan cara efisien dan efektif yang menentukan bahwa peradilan dilakukan dengan sederhana, cepat dan biaya ringan. Sederhana dapat juga dimaknai sebagai suatu proses yang tidak berbelit-belit, tidak rumit, jelas, lugas, non interpretable, mudah dipahami, mudah dilakukan, mudah diterapkan, sistematis, konkrit baik dalam sudut pandang pencari keadilan, maupun dalam sudut pandang penegak hukum yang mempunyai tingkat kualifikasi yang sangat beragam, baik dalam bidang potensi pendidikan yang dimiliki, kondisi sosial ekonomi, budaya dan lain-lain. ${ }^{24}$

23 Sunaryo et. al., Op.Cit. hlm 47.

24 Ibid hlm.46. 
Biaya ringan mengandung makna bahwa mencari keadilan melalui lembaga peradilan tidak sekedar orang mempunyai harapan akan jaminan keadilan di dalamnya tetapi harus ada jaminan bahwa keadilan tidak mahal, keadilan tidak dapat dimaterialisasikan dan keadilan yang mandiri serta bebas dari nilai-nilai yang merusak nilai keadilan itu sendiri. ${ }^{25}$ Selain itu, biaya ringan dimaksudkan agar terpikul oleh rakyat. Biaya perkara yang tinggi kebanyakan menyebabkan pihak yang berkepentingan enggan untuk mengajukan tuntutan hak kepada pengadilan. Asas contante justitie ini menjadi hal mutlak yang harus diterapkan dalam setiap tingkat pengadilan. Jika asas ini diterapkan secara konsekuen di pengadilan, maka diharapkan akan tercipta suatu kepercayaan terhadap badan peradilan.

Dalam upaya untuk menegakkan asas dan hukum itu sendiri, tentunya tidak bisa terlepas dari kekuasaan. Hubungan hukum dan kekuasaan dalam masyarakat, oleh Mochtar Kusumaatmadja digambarkan sebagai berikut: "hukum memerlukan kekuasaan bagi pelaksanaannya, sebaliknya kekuasaan itu sendiri ditentukan batas-batasnya oleh hukum." Secara populer, kesimpulan ini barangkali dapat dirupakan dalam slogan bahwa: "hukum tanpa kekuasaan adalah angan-angan, kekuasaan tanpa hukum adalah kelaliman. ${ }^{" 26}$ Dengan demikian, secara analitik, dapatlah dikatakan bahwa kekuasaan merupakan suatu fungsi dari masyarakat yang teratur.

25 Ibid hlm.48.

26 Mochtar Kusumaatmadja (tt), Fungsi dan Perkembangan Hukum Dalam Pembangunan Nasional, Bandung: Bina Cipta, hlm.4.
Kekuatan fisik (force) dan wewenang resmi (formal authority) merupakan dua sumber kekuasaan. Persoalannya, apakah kekuasaan itu adalah wewenang dan kekuatan fisik? Tidak, wewenang formal dan kekuatan fisik bukan satu-satunya sumber kekuasaan. Memang dalam kenyataan, orang yang memiliki pengaruh politik atau keagamaan dapat lebih berkuasa dari pada orang yang berwenang atau memiliki kekuatan fisik. Kekayaan (uang) atau kekuatan ekonomi lainnya juga merupakan sumbersumber kekuasaan yang penting, sedangkan dalam keadaan-keadaan tertentu kejujuran, moral yang tinggi dan pengetahuan pun tak dapat diabaikan sebagai sumber-sumber kekuasaan. Jadi, kekuasaan adalah fenomena yang beraneka ragam bentuknya dan banyak macam sumbernya. Hanya, pada hakikatnya kekuasaan itu tetap sama, yaitu kemampuan seseorang untuk memaksakan kehendaknya atas pihak lain.

Secara epistemologis, baik atau buruknya kekuasaan itu sendiri sangat tergantung dari bagaimana cara menggunakan kekuasaan. Artinya, baik buruknya kekuasaan senantiasa harus diukur dengan kegunaannya untuk mencapai suatu tujuan yang sudah ditentukan. Unsur pemegang kekuasaan merupakan faktor penting dalam hal digunakannya kekuasaan yang dimilikinya sesuai dengan kehendak masyarakat. Karena bagi pemegang kekuasaan diperlukan syarat antara lain kejujuran dan rasa pengabdian yang tinggi terhadap kepentingan masyarakat. ${ }^{27}$ Ia merupakan suatu yang mutlak bagi

27 Lily Rasjidi dan Ira Thania Rasjidi, (2002). Pengantar Filsafat Hukum. Bandung: Mandar Maju, hlm 71 . 
kehidupan masyarakat yang tertib, bahkan bagi setiap organisasi yang teratur seperti Negara. ${ }^{28}$

Ditinjau dari aspek aksiologi, pandangan tentang hubungan hukum dan kekuasaan itu sebenarnya tidaklah tunggal. Antara kaum idealis yang berorientasi pada das sollen dan kaum empiris yang lebih melihat hukum sebagai das sein, memberikan pandangan yang berbeda. Namun, kedua pandangan itu sama-sama sependapat bahwa seharusnya hukum itu supreme atas kekuasaan. Ketika kita melihat teori yang ditawarkan oleh Roscue Pound, bahwa "law as a tool as social engineering”, maka kita akan melihat bahwa hukum harus mempengaruhi kehidupan masyarakat. Tetapi, manakala kita mengacu ajaran Von Savigny, yang mengatakan bahwa "hukum berubah jika masyarakatnya berubah", maka hukum semestinya harus mampu mengikuti perkembangan dan memenuhi tuntutan masyarakat.

Dalam konteks ini, pelaksanaan kekuasaan kehakiman di Indonesia, juga terikat pada hukum acara masing-masing sebagai hukum formil yang mengatur tata cara penyelenggaraan persidangan atau peradilan. Di dalam lingkup peradilan pidana umum dan khusus, dikenal Kitab Undang-undang Hukum Acara Pidana (KUHAP) dan ketentuan hukum acara yang mengatur peradilan Tipikor, peradilan HAM Berat, peradilan Teroris, peradilan narkotika/psikotropika. Di dalam lingkup peradilan perdata umum dan khusus, dikenal Burgerlijke Wetboek ( $B W)$, Het Herziene Indische Reglement (HIR) dan Rechtsreglement van Buitengewisten (RBg),

28 Soerjono Soekanto. (1977). Sosiologi. Jakarta: Yayasan Penerbit Universitas Indonesia, hlm 19. serta ketentuan-ketentuan hukum acara bagi peradilan hubungan industrial, peradilan niaga/kepailitan, peradilan persaingan usaha, peradilan pajak. Di lingkup peradilan agama, dikenal hukum acara peradilan agama. Dimana pada seluruh ketentuan hukum acara masing-masing peradilan semuanya tunduk pula pada asas contante justitie yang diatur pada ketentuan Pasal 2 ayat (4) Undang-undang Nomor 48 tahun 2009 tentang Kekuasaan Kehakiman, bahwa "peradilan dilakukan dengan sederhana, cepat, dan biaya ringan".

Namun demikian, pelaksanaan asas contante justitie dalam beracara pada pengadilan di Indonesia saat ini, menjadi tertinggal serta tidak lagi cepat, sederhana dan murah jika dibandingkan dengan tersedianya sarana modern dalam era komputerisasi sekarang ini. Hampir semua pengadilan di Indonesia masih menerapkan secara kaku dan tradisional hukum acara peradilannya. Kekakuan ini termasuk pula dengan tetap memberlakukan tahapan-tahapan proses beracara yang banyak memakan waktu dan biaya ketimbang manfaat dan tujuan acara itu sendiri.

Proses tersebut antara lain, di peradilan perdata (umum dan khusus) dan peradilan TUN masih dikenal proses jawab menjawab dalil/dalih yang memakan waktu tidak kurang dari 4 (empat) minggu, di peradilan pidana (umum dan khusus) juga dikenal dengan proses pengajuan eksepsi dan tanggapan yang memakan waktu 3 (tiga) minggu, bahkan penyelesaian sengketa Pemilukada di Mahkamah Konstitusi R.I. yang terkenal dengan julukan speedy trial ternyata masih membutuhkan waktu 2 (dua) kali per- 
sidangan, walaupun pada acara penyerahan perbaikan gugatan dan kesimpulan sudah menggunakan media internet.

Proses jawab-menjawab memakan waktu hingga sehari penuh di setiap persidangan selama berminggu-minggu, yang sebenarnya hanyalah proses yang dapat dilakukan 10 menit karena substansinya hanyalah mengantarkan, membagikan dan menerima surat, namun karena harus dilakukan di depan persidangan maka proses tersebut menjadi membengkak bisa menjadi seharian penuh akibat antrian jadwal persidangan pada hari yang sama, yang terus berulang lagi selama beberapa minggu. Proses jawab-menjawab ini tidak hanya banyak membuang waktu seluruh pihak, bahkan juga memakan biaya yang tidak sedikit.

Bagi pihak-pihak yang berperkara di pengadilan tempat tinggalnya, tentu masih membutuhkan biaya transportasi dan makan siang pada saat menghadiri sidang "sepuluh menit" tersebut. Apalagi bagi pihakpihak yang bertempat tinggal di kota lain dari pengadilan yang mengadili perkaranya, maka biaya itu mencakup pula biaya transportasi jarak jauh, biaya penginapan dan biaya konsumsi yang tidak sedikit setiap kali menghadiri persidangan "serah terima surat" tersebut. Dengan adanya teknologi internet, maka diharapkan proses beracara tersebut dapat menjadi jauh lebih cepat, sederhana dan murah dibanding keadaan saat ini.

\section{Sinergitas Proses Beracara dengan Meng- gunakan Media E-mail untuk Mewujud- kan Asas Contante Justitie}

Asas contante justitie ini menjadi hal mutlak yang harus diterapkan dalam setiap tingkat pengadilan. Jika asas ini diterapkan secara konsekuen di pengadilan, maka diharapkan akan tercipta suatu kepercayaan terhadap badan peradilan. Proses jawab-menjawab yang dilakukan selama ini di pengadilan ialah dimulai ketika pihak yang satu diberi kesempatan untuk menanggapi dalil yang dikemukakan pihak lainnya. Misalnya dalam perkara perdata, agama dan TUN, ketika Tergugat diberi kesempatan untuk menanggapi surat gugatan Penggugat, begitu pula dalam perkara pidana ketika Terdakwa diberi kesempatan mengajukan eksepsi atas surat dakwaan Penuntut Umum. Sedangkan dalam proses beracara di Mahkamah Konstitusi, ketika Termohon diberi kesempatan untuk menanggapi dalil permohonan Pemohon. Selanjutnya, saling menanggapi secara tertulis ini berlangsung dengan memberikan kesempatan bagi kedua belah pihak masingmasing sebanyak dua kali (gugatan/dakwaan, eksepsi/jawaban, replik dan duplik).

Sidang pengajuan tanggapan atau jawab-menjawab itu sendiri tidak semudah mengantarkan surat belaka. Namun membutuhkan waktu dan biaya yang tidak sedikit, di mana setiap kali pengajuan harus dilakukan di depan persidangan yang dibuka dengan resmi. Di sini terdapat hambatan contante justitie, karena bagaimanapun juga pelaksanaan sidang ini harus menunggu antrian dengan sidang-sidang lainnya pada saat yang sama, menunggu hakim, panitera dan para pihak telah hadir semuanya, barulah sidang dapat dibuka dan kemudian agendanya hanya menerima pengajuan surat tanggapan tersebut. Hambatan penerapan contante justitie juga terjadi ketika para pihak yang berkedudukan di lain kota, dimana pihak 
tersebut harus mengorbankan biaya dan waktu yang banyak untuk bisa hadir dalam sidang penyerahan surat tersebut. Hal ini tidak saja berlangsung sekali, namun terjadi sekurang-kurangnya empat kali persidangan dalam satu perkara.

Selain itu, terhambatnya penerapan asas contante justitie ini juga dapat dimanfaatkan oleh para pihak yang diuntungkan jika waktu berlarut-larut. Di mana pihak tersebut dapat saja menunda sidang dengan berbagai alasan, sehingga mau tidak mau sidang ditunda lagi ke minggu berikutnya. Tidak heran jika suatu perkara prosesnya sejak dari didaftarkan sampai jatuhnya putusan, dapat memakan waktu antara 4-12 bulan lamanya, yang antara lain karena tidak terlaksananya asas contante justitie dalam persidangan perkara tersebut.

Ditinjau dari aspek keamanan dan ketertiban sidang di pengadilan, maka proses jawab-menjawab yang memakan waktu dan biaya ini juga memberikan sumbangsih potensi instabilitas. Di mana dalam perkaraperkara yang rawan bentrokan antara para pihak, setiap kali persidangan pendukung atau keluarga masing-masing pihak bertemu di pengadilan. Pada saat-saat jenuh menunggu atau pulang dari persidangan, hal-hal kecil bisa saja menjadi pemicu bentrok di antara para pihak. Padahal substansi proses hukum acara itu sendiri semata-mata hanyalah penyerahan surat, namun kadangkala tidak terhindarkan timbulnya perkelahian atau pertengkaran antara kedua belah pihak.

Interconnection network (internet) adalah sistem global dari seluruh jaringan komputer yang saling terhubung dengan cara menghubungkan komputer satu dengan komputer lainnya agar bisa saling berkomunikasi. Pada tahun 1980 dibuatlah protokol resmi yang dikenal dengan TCP/IP (Transmission Control Protocol/Internet Protocol) untuk menyeragamkan tujuan tersebut.

Pada awal kemunculannya, internet disebut ARPANET dan hanya merupakan jaringan komputer yang kecil sekali, yang menghubungkan beberapa komputer dari University of California at Los Angeles (UCLA), Stanford Research Institute, University of California at Santa Barbara, dan University of Utah di Amerika. Sejak saat itulah, internet mulai dipergunakan di universitas-universitas yang ada di Amerika. Pada tahun 1986 internet mulai digunakan secara terbuka oleh umum. Sejak saat itu penggunaan internet berkembang dengan sangat cepat ke seluruh dunia.

Bila dibandingkan dengan alat-alat komunikasi lainnya, internet merupakan alat komunikasi yang paling cepat berkembang. Pada tahun 1989 jumlah jaringan yang tergabung ke internet berkembang dengan pesat. Di bulan Januari jumlah jaringan yang tergabung ke Internet sebanyak 80.000 bertambah menjadi 130.000 di bulan Juli dan melebihi 160.000 di bulan November. Beberapa negara seperti Australia, Jerman, Israel, Italia, Jepang, Meksiko, Belanda, Selandia Baru, dan Inggris bergabung dengan internet. Pada tahun 1995 diperkirakan 25 juta orang telah menjadi pengguna internet. Data dan lembaga penelitian IDC menyebutkan bahwa pada tahun 1999 pengguna internet diperkirakan telah mencapai 196 juta orang dan menjadi 502 juta orang pada tahun 2003. Menurut Internet World Statistics, saat ini pengguna internet telah mencapai 
1.076.203.987 orang yang tersebar di seluruh dunia. Jika penduduk dunia 6.499.697.060 orang, ini berarti $16,56 \%$ penduduk dunia telah terhubung ke internet.

Perkembangan penggunaan internet di Indonesia juga tidak kalah cepat. Pada tahun 1995 pengguna di Indonesia mencapai 10.000 orang. Jumlah ini rneningkat $10 \mathrm{kali}$ lipat pada tahun 1997. Pada tahun 2000 jumlah pengguna internet di Indonesia, menurut data dan lembaga survey eTForcasts, sebesar 2.000.000 orang. Jumlah tersebut meningkat pada tahun berikutnya, menurut data yang dikeluarkan oleh Asosiasi Penyelenggara Jasa Internet Indonesia (APJII), pada tahun 2001 pengguna internet di Indonesia mencapai 2,4 juta orang.

Pada tahun 2004, jumlah pengguna internet di Indonesia telah mencapai 4,2 juta orang dan diperkirakan pada tahun 2005 jumlah pengguna di Indonesia akan mencapai 5 juta orang. Kenyataannya, jumlah pengguna internet pada tahun 2005 jauh lebih besar dan yang diperkirakan. Menurut eTForcasts, jumlah pengguna internet di Indonesia pada tahun 2005 telah mencapai 18.000.000 orang atau 3,6 kali lebih besar dan yang diperkirakan. Di dunia, Indonesia merupakan negara dengan jumlah pengguna internet terbesar ke-15. Sedangkan untuk kawasan Asia, Indonesia merupakan negara dengan jumlah pengguna internet terbesar kelima di bawah Cina, Jepang, India dan Korea Selatan. ${ }^{29}$

Internet menjadi alat komunikasi dan sumber informasi yang sangat andal. Kita

29 Sebagaimana dikutip pada laman website: $\underline{\text { http:// }}$ komunikasi.us/index.php/course/perkembanganteknologi-komunikasi/3422-internet-pada-eramasa-kini (Diakses 31 Juli 2015). dapat berkomunikasi dengan orang di seluruh dunia dengan menggunakan internet dalam waktu yang sangat cepat dan biaya yang murah. Aplikasi internet yang banyak digunakan untuk berkomunikasi adalah $e$ mail dan chatting. Belakangan ini, kemajuan jaringan internet yang memungkinkan akses internet melalui pita lebar sehingga akses menjadi lebih cepat dan data yang dilewatkan bisa lebih besar, komunikasi dengan menggunakan konferensi video mulai banyak digunakan.

E-mail adalah singkatan dari kata Electronic Mail, yaitu surat atau pesan elektronik yang dikirimkan dan diterima melalui jaringan internet. Dengan e-mail, maka pesan yang dikirimkan akan sampai kepada penerima pada seketika itu juga. Dibandingkan dengan pengiriman surat melalui jasa pengiriman, maka e-mail telah memangkas waktu tempuh secara ekstrim. Selain itu, e-mail dapat pula mengirimkan surat elektronik yang disertai dengan grafik, gambar, foto, suara, animasi serta dapat dilakukan untuk mengirimkan ke beberapa alamat tujuan sekaligus.

E-mail atau kalau dalam istilah Indonesia, surat elektronik, adalah aplikasi yang memungkinkan para pengguna internet untuk saling berkirim pesan melalui alamat elektronik di internet. Para pengguna email memilki sebuah mailbox (kotak surat) elektronik yang tersimpan dalam suatu mailserver. Suatu Mailbox memiliki sebuah alamat sebagai pengenal agar dapat berhubungan dengan mailbox lainnya, baik dalam bentuk penerimaan maupun pengiriman pesan. Pesan yang diterima akan ditampung dalam mailbox, selanjutnya pemilik mail- 
box sewaktu-waktu dapat mengecek isinya, menjawab pesan, menghapus, atau menyunting dan mengirimkan pesan email.

Layanan e-mail biasanya dikelompokkan dalam dua basis, yaitu e-mail berbasis client dan e-mail berbasis web. Bagi pengguna e-mail berbasis client, aktifitas peremailan dilakukan dengan menggunakan perangkat lunak e-mail client, misalnya Eudora atau Outlook Express. Perangkat lunak ini menyediakan fungsi-fungsi penyuntingan dan pembacaan e-mail secara offline (tidak tersambung ke internet). Dengan demikian, biaya koneksi ke internet dapat dihemat. Koneksi hanya diperlukan untuk melakukan pengiriman (send) atau menerima (recieve) email dari mailbox. Sebaliknya, bagi pengguna email berbasis web, seluruh kegiatan per-emailan harus dilakukan melalui suatu situs web. Dengan demikian, untuk menggunakannya haruslah dalam keadaan online. Alamat e-mail dari ISP (Internet Service Provider) umumnya berbasis client, sedangkan email berbasis web biasanya disediakan oleh penyelenggara layanan email gratis seperti Hotmail (www.hotmail.com) atau YahooMail (mail.yahoo.com).

Pada mulanya, sistem e-mail hanya dapat digunakan untuk mengirim informasi dalam bentuk teks standar (dikenal sebagai ASCII, American Standard Code for Information Interchange). Saat itu, sukar untuk mengirimkan data yang berupa berkas non-teks (dikenal sebagai file binary). Cara umum dilakukan kala itu adalah dengan menggunakan program uuencode untuk mengubah berkas binary tersebut menjadi berkas ASCII, kemudian baru dikirimkan melalui e-mail. Di tempat tujuan, proses sebaliknya dilakukan, yaitu berkas ASCII tersebut diubah kembali ke berkas binary dengan menggunakan program uudecode. Cara ini terlalu kompleks (tidak terintegrasi dengan sistem e-mail).

Belakangan dikembangkan standar baru yang disebut MIME (Multipurpose Internet Mail Extensions). Standar ini diciptakan untuk mempermudah pengiriman berkas dengan melalui attachment. MIME juga memungkinkan sebuah pesan dikirimkan dalam berbagai variasi jenis huruf, warna, maupun elemen grafis. Walaupun nampak menarik, penggunaan MIME akan membengkakkan ukuran pesan email yang dikirimkan. Hal ini jelas akan memperlambat waktu yang dibutuhkan untuk mengirim maupun menerima pesan. Dalam hal ini, ada anjuran agar sedapat mungkin menggunakan format teks standar dalam penyuntingan email. Gunakan MIME hanya untuk pesanpesan tertentu yang memang membutuhkan tampilan yang lebih kompleks.

Durasi waktu yang dibutuhkan sebuah perangkat komputer untuk tersambung dan mengirimkan data kepada komputer lain yang terhubung, berjalan dengan sangat singkat, yaitu dalam hitungan detik. Dengan kata lain, tanpa beranjak dari kursi, seorang pengetik bisa langsung seketika itu mengirimkan hasil ketikannya kepada komputer penerima, biaya banyak dan proses lisan yang berlebihan.

Kendala mungkin ditemukan dalam penggunaan media internet e-mail dalam beracara jawab-menjawab di pengadilan, dalam hal-hal sebagai berikut:

a) Tempat tinggal para pihak tidak terjangkau signal/akses internet. 
b) Para pihak tidak dapat membaca, menulis atau tidak mengetahui cara menggunakan teknologi internet.

c) Signal/akses internet setempat terputus pada saat mendekati batas waktu pengajuan surat jawab menjawab yang telah ditetapkan.

Namun ditemukan pula kondisi yang menguntungkan untuk menerapkan penggunaan media internet e-mail ini, yaitu:

a) Seluruh pengadilan di Indonesia telah dilengkapi dengan peralatan berbasis internet dalam rangka mendukung program keterbukaan informasi peradilan.

b) Seluruh Advokat dipandang telah mampu menggunakan media komputer dan media internet dalam kegiatan sehari-harinya.

c) Penggunaan alamat e-mail telah cukup luas dikenal dan digunakan oleh sebagian besar masyarakat di Indonesia, seiring dengan meluasnya penggunaan media sosial oleh masyarakat seperti facebook, whats-app, line, blackberry messenger,path dan lain-lain yang semuanya mensyaratkan adanya alamat e-mail bagi penggunanya.

Perangkat keras (hardware) sebagai sarana untuk menggunakan e-mail telah tersedia di tengah masyarakat dengan cukup banyak varian, seperti personal computer ( $p c)$, laptop, notebook, dan smart phone. Bahkan sarana hardware yang dapat digunakan umum juga tersedia di usahausaha warnet (warung internet yang ada setidaknya di ibukota Kabupaten-kabupaten di seluruh Indonesia.

Jika menggunakan media internet email dalam proses jawab menjawab di pe- ngadilan, maka diharapkan dapat memangkas waktu, biaya dan potensi instabilitas. Di mana dapat dimulai pada saat sidang pertama dibuka, Hakim memberitahukan tata cara dan jadwal diterimanya surat jawab menjawab tersebut dari para pihak, tanpa memerlukan kedatangan para pihak ke pengadilan.

Tata cara pengiriman dan penerimaan surat jawab-menjawab tersebut dapat dilakukan dengan cara sebagai berikut :

a) Panitera dan para pihak memberitahukan alamat e-mail masing-masing, yang kemudian disahkan oleh Hakim sebagai alamat korespondensi yang sah dan berlaku tetap dalam perkara tersebut.

b) Hakim menentukan tanggal dan jam serta batas waktu pengajuan surat jawab menjawab yang sah, jika lewat dari waktu yang ditentukan maka pihak yang terkena gilirannya dianggap telah melepaskan haknya untuk mengajukan surat jawab menjawab tersebut.

c) Hakim dapat pula menetapkan bahwa alamat e-mail yang sudah disahkan tersebut, merupakan alamat penyampaian pemberitahuan/panggilan yang sah dan patut kepada para pihak yang berperkara, dengan tetap mengacu pada toleransi waktu penyampaian/panggilan yang patut menurut hukum acara.

d) Pihak yang gilirannya mengajukan surat jawab-menjawab, wajib mengirimkan surat jawab-menjawabnya kepada seluruh pihak lawan dan panitera sesuai dengan batas waktu yang telah ditetapkan.

e) Pada saat persidangan di pengadilan, yaitu tahap pembacaan putusan sela 
dan/atau tahap pembuktian, Hakim memberitahukan surat jawab-menjawab yang sudah masuk serta melakukan cross check apakah telah diterima oleh seluruh pihak.

f) Hakim dapat menggunakan media internet e-mail ini sekali lagi, yaitu pada saat pengajuan kesimpulan (conclusie) oleh para pihak.

Jika menggunakan media internet email dalam proses beracara jawab-menjawab di pengadilan, maka kurun waktu paling cepat 1 (satu) bulan yang selama ini dibutuhkan dalam beracara secara manual, dapat dipangkas menjadi kurang dari 10 (sepuluh) hari saja. Begitu pula dengan biaya yang tadinya diperlukan setiap pihak (minimal Rp.200.000 bagi pihak lokal, dan minimal Rp.500.000,- bagi pihak yang berasal dari kota lain) setiap kali harus menghadiri sidang, dapat dipangkas menjadi Rp.0 jika menggunakan media internet e-mail ini.

Namun hinggga saat ini, media e-mail belum dapat digunakan dalam beracara proses jawab-menjawab di pengadilan. Oleh karena adanya kendala di mana setiap hukum acara masing-masing pengadilan masih mewajibkan untuk menghadiri dan mengajukan fisik surat jawab-menjawab tersebut di depan persidangan.

\section{PENUTUP}

Asas contante justitie telah diatur dalam ketentuan peraturan perundang-undangan di Indonesia, yaitu pada Pasal 2 ayat (4) Undang-undang Nomor 48 tahun 2009 tentang Kekuasaan Kehakiman, serta pada ketentuan Hukum Acara masing-masing peradilan. Namun pelaksanaannya masih ketinggalan za- man, khususnya pada proses beracara jawab-menjawab, karena dilaksanakan secara "tradisional" dengan mewajibkan para pihak untuk menghadiri dan mengajukan fisik surat jawab-menjawab tersebut di depan persidangan. Sedangkan pada era komputerisasi saat ini, sudah dikenal adanya korespondensi dengan menggunakan media internet e-mail.

Sinergitas proses beracara jawab-menjawab yang lebih cepat dan lebih murah jika menggunakan sarana media internet e-mail, tentunya sangat mendukung terwujudnya asas contante justitie dalam proses beracara di pengadilan secara lebih efektif dan efisien. Oleh karenanya, diharapkan agar Hukum Acara pada pengadilan-pengadilan di Indonesia dapat disesuaikan dengan adanya perkembangan tekonologi e-mail ini. Setidaknya Mahkamah Agung dan Mahkamah Konstitusi mengeluarkan regulasi guna membolehkan penggunaan media e-mail dalam proses beracara jawab-menjawab.

\section{BIBLIOGRAFI}

Abdul Ghofur. (2006). Filsafat Hukum, Cet. 1. Yogyakarta: Gajah Mada University Press.

Algera, et. al. (1983). Kamus Istilah Hukum Indonesia Belanda, Jakarta.

Bambang Sutiyoso. (2007). Metode Penemuan Hukum, Cet. 2. Yogyakarta: UII Press.

Bruggink. (1999). Refleksi tentang Ilmu Hukum, Alih Bahasa: Arief Sidharta. Bandung: Citra Aditya Bakti.

Khudzaifah Dimyati. (2004). Teorisasi Hukum, Cet. 2. Yogyakarta: Muhammadiyah University Press.

Komunikasi. Available online at: http://goo. gl/UiOQHA (Diakses 31 Juli 2015). 
Kusnu Goesnadhie. (2006). Harmonisasi Hukum, Cetakan pertama. Surabaya: JP. Books.

Lily Rasjidi dan Ira Thania Rasjidi, (2002). Pengantar Filsafat Hukum. Bandung: Mandar Maju.

Mochtar Kusumaatmadja. (tanpa tahun), Fungsi dan Perkembangan Hukum dalam Pembangunan Nasional, Bandung: Bina Cipta.

Notohamidjojo. (1957). Soal-Soal Pokok Filsafat Hukum. Jakarta: BPK Gunung Mulia.

Paul Scholten. (1988). Verzamelde Geschriffen, definitif Sudikno Mertokusumo, Mengenal Hukum. Yogyakarta: Liberty.
Satjipto Rahardjo. (1986). Ilmu Hukum. Bandung: Alumni.

Soerjono Soekanto. (1977). Sosiologi. Jakarta: Yayasan Penerbit Universitas Indonesia.

Sudikno. (2006). Hukum Acara Perdata, Edisi VII, Cet. 1. Yogyakarta: Liberty.

Sunaryo, T.M., Tjoek, W dan Aris, H., (2004). Pengelolaan Sumber Daya Air. Denpasar: Universitas Udayana.

Suparto. (1975). Demi Keadilan dan Kemanusiaan, Beberapa Cabang Filsafat Hukum. Jakarta: BPK Gunung Mulia.

Zainuddin Ali. (2011). Metode Penelitian Hukum. Ed. 1 Cet. 3. Jakarta: Sinar Grafika. 